\title{
Summary of U.S. Balance of Payments, 1969
}

\author{
by MICHAEL W. KERAN
}

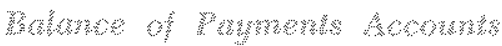

The Balance of Payments Accounts are a double-entry record of commodity and financial transactions between United States and foreign residents. Because it is based on double-entry bookkeeping principles, the balance of payments always balances in the sense that receipts equal payments. The double entry nature of the balance of payments is illustrated on the lefthand side of the table on the next page. This accounting balance must not be confused, however, with a meaningful economic balance, because the economic behavior underlying some of these transactions may not be sustainable. For example, the receipt of $\$ .8$ billion in 1969 from the sale of convertible currencies (IV.3.b) can only continue as long as the United States' stock of convertible currencies lasts. There are two officially recognized measures of the economic balance of payments: the Liquidity $\mathrm{Bal}+$ ance and the Official Settlements Balance. They represent alternative ways of arranging the balance of payments accounts, and are shown on the righthand side of the table.

The Accounts are divided into four categories: Goods and Services, Private Capital, Government, and Other. These accounts are, of course, interrelated; an export of goods can be financed by private capital, a Government loan or grant, or by a private transfer.

(I) Goods and Services - Merchandise exports and imports (I.1.) are a measure of physical goods which cross national boundaries. The demand for imports depends largely upon domestic income, while the demand for exports depends largely upon the level of income abroad. Because of excess demand in the United States, the trade balance of $\$ .7$ billion is unusually small by historic U.S. standards. However, there was a pattern of improvement during the year due to the slowdown in the United States economy which reduced import growth, while exports continued to grow rapidly in response to high levels of demand in Europe and Japan.

In spite of the decline in U.S. troops in Vietnam, military spending abroad increased $\$ .4$ billion in 1969 to a level of $\$ 4.9$ billion (I.2.a). Other components of services were relatively unchanged from 1968.

(II) Private Capital - Long-term capital (II.1.) represents changes in United States private assets purchased from foreigners (payments column) and liabilities to foreigners (receipts column). There was a long-term capital outflow of $\$ .7$ billion in 1969 versus an inflow of $\$ 1.9$ billion in 1968 . This turnaround is attributed largely to a decrease in foreign private and official portfolio investment in the United States.

For short-term capital (II.2.), the payments column represents changes in all private United States assets, while the receipts column records only changes in private nonbank liabilities, and thus does not record Euro- dollar transactions. Changes in bank liabilities are listed with changes in short-term Treasury liabilities under IV.4, to facilitate analysis of the distinction between the Liquidity Balance and Official Settlements Balance.

(III) Government - The net outflow of Govemment loans, grants, and transfers was $\$ 4.0$ billion in 1969 , up $\$ 1.5$ billion from 1968. Foreign official institutions, which had purchased $\$ 1.8$ billion of U.S. Government bonds in 1968 , sold $\$ .2$ billion in 1969 . This $\$ 2.0$ billion turnaround more than explains the deterioration in the Govermment capital account.

(IV) Other - Private transfers (IV.1.) represent gifts and similar payments by American residents to foreign residents. Errors and Omissions (IV.2.) is the statistical discrepancy between all specifically identifiable receipts and payments. The importance of this item is discussed below. Changes in U.S. Reserve Assets (IV.3.) represent official transactions of the United States Government with foreign governments and the International Monetary Fund (IMF). The $\$ 1.2$ billion increase in reserve assets is recorded with a minus sign because dollars were "spent" to acquire them. Changes in U.S. Liquid Liabilities (IV.4.) represent increased foreign holdings of liquid dollar liabilities of U.S. banks and the Treasury. The major difference between the Liquidity and the Official Settlements Balances is in the different categorizing of these U.S. Liquid Liabilities.

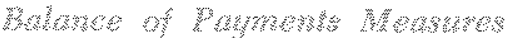

The Net Balance columns show the source and overall size of the deficit or surplus, while the Financing columns show how the deficit is financed or the surplus is disposed.

Liquidity Balance - The underlying assumption about economic behavior is that all foreign liquid dollar holdings (IV.4) both private and official, are a potential claim on United States reserve assets, especially the gold stock. The Liquidity Balance was in deficit by $\$ 7$ billion in 1969 , compared to a $\$ .2$ billion surplus in 1968 . This great change is partially a statistical illusion resulting from two specific events which in no way rehect a weakening in the basic external position of the United States. First, Federal Reserve Regulation $Q$, which imposed an interest rate ceiling of $6 \frac{1}{4}$ per cent or less on deposits in American banks, created an incentive for many depositors to switch their deposits to the foreign branch offices of American banks where Regulation $Q$ did not apply and interest rates were in excess of 9 per cent. As the transfers were outside usual Department of Commerce reporting channels, they show up in Errors and Omissions, which increased from a $\$ .7$ billion deficit in 1968 to a $\$ 3$ billion deficit in 1969 . Second, offichal institutions switched their dollar reserves from "nonliquid" Treasury notes and corporate bonds to "liquid" form by $\$ 1$ billion in 1969 . 
Official Settlement Balance-The underlying economic rationale is that only official holdings of dollars represent a meaningful potential claim on U.S. reserve assets. Foreign private persons and international organizations demand dollar balances to meet the needs of international trade and finance. Thus, an increase in foreign private holdings of dollars (IV.4.b) is treated as a capital inflow, while changes in foreign official holdings of dollars (IV.4.a) is treated as a fmancing item. The Official Settlements Balance recorded a surplus of $\$ 2.7$ billion in 1969, almost double the surplus recorded in
1968. This undoubtedly overstates the underlying strength of the balance of payments, because the $\$ 8.8$ billion capital inflow through the Eurodollar market (IV.4.b) was mainly due to the need of U.S. banks to find sources of funds not subject to Regulation $Q$ interest rate ceilings.

Conclusion - Regulation $Q$ has cistorted both of these measures in 1969, making one look stronger and the other weaker than it really was. These measurement problems cantion us not to rely on summary statements about the balance of payments. This is especially true of a reserve currency country like the United States.

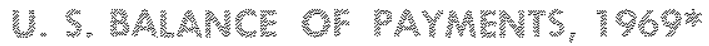 (In Billions of Dollars)}

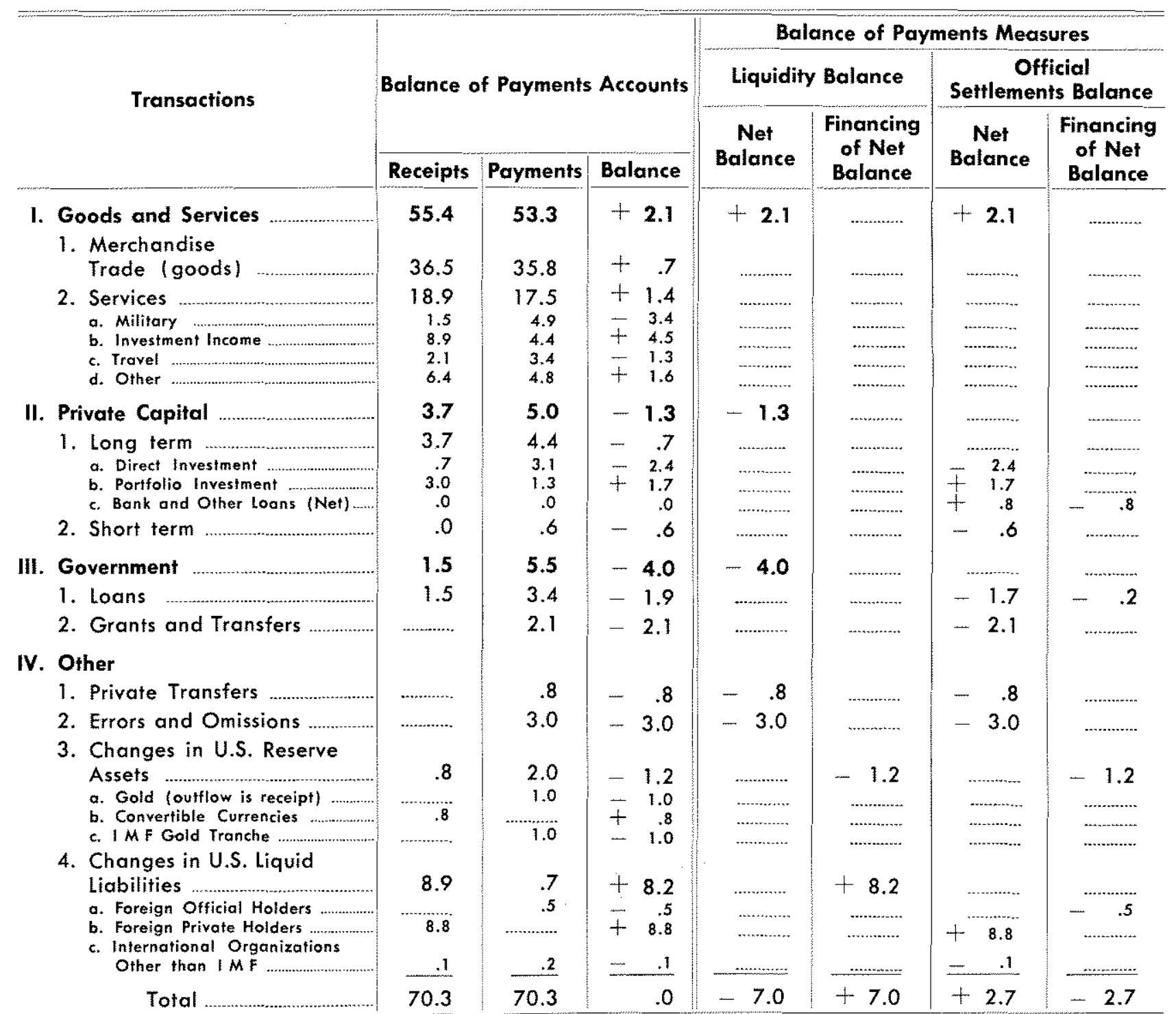

Note: Figures may not add because of rounding.

*Preliminary 